\title{
Analyst
}

MINIREVIEW

CrossMark

\& click for updates

Cite this: Analyst, 2016, 141, 1185

Received 25th October 2015, Accepted 8th January 2016

DOI: 10.1039/c5an02208h

www.rsc.org/analyst
View Article Online

View Journal I View Issue

\section{Electrochemical hydrogen sulfide biosensors}

\author{
Tailin Xu, ${ }^{a}$ Nikki Scafa, ${ }^{b}$ Li-Ping Xu, ${ }^{* a}$ Shufeng Zhou, ${ }^{c}$ Khalid Abdullah Al-Ghanem, ${ }^{d}$ \\ Shahid Mahboob, ${ }^{d}$ Bunshi Fugetsu ${ }^{e}$ and Xueji Zhang*a,b
}

\begin{abstract}
The measurement of sulfide, especially hydrogen sulfide, has held the attention of the analytical community due to its unique physiological and pathophysiological roles in biological systems. Electrochemical detection offers a rapid, highly sensitive, affordable, simple, and real-time technique to measure hydrogen sulfide concentration, which has been a well-documented and reliable method. This review details up-to-date research on the electrochemical detection of hydrogen sulfide (ion selective electrodes, polarographic hydrogen sulfide sensors, etc.) in biological samples for potential therapeutic use.
\end{abstract}

\section{Introduction}

Hydrogen sulfide $\left(\mathrm{H}_{2} \mathrm{~S}\right)$ is well known as a colorless, flammable, and water soluble gas with the distinctive smell of rotten eggs and has received attention as a toxic gas and as an environmental hazard for many decades. ${ }^{1}$ Recent research has found that $\mathrm{H}_{2} \mathrm{~S}$ is a common constituent of mammalian

${ }^{a}$ Research Center for Bioengineering and Sensing Technology, University of Science and Technology Beijing, Beijing 100083, China. E-mail: xuliping@ustb.edu.cn, zhangxueji@ustb.edu.cn

${ }^{b}$ World Precision Instruments, Sarasota, FL 34240-9258 USA

${ }^{c}$ College of Pharmacy, University of South Florida, East Fowler Ave, Tampa, Florida 33620-4202, USA

${ }^{d}$ Department of Zoology, College of Science, King Saud University, P.O. Box 2455, Riyadh-11451, Saudi Arabia

${ }^{e}$ Policy Alternative Research Institute, The University of Tokyo, Tokyo 113-0032, Japan

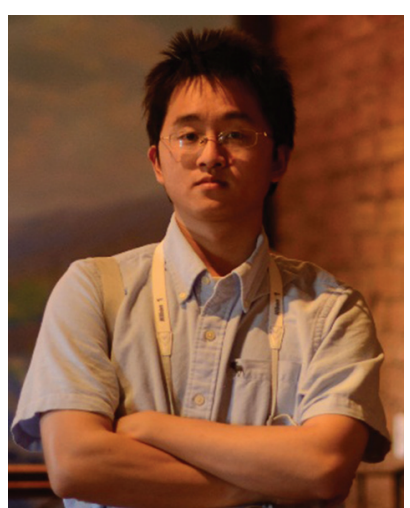

Tailin Xu
Tailin Xu received his BSc degree in Chemistry at the School of Chemistry and Biological Engineering, University of Science \& Technology Beijing (USTB, P. R. China). He then joined the Research Center for Bioengineering \& Sensing Technology research group at USTB to pursue his PhD degree under the supervision of Prof. Xueji Zhang. From 2013 to 2015, he joined Joseph Wang's group as a joint PHD student at the University of California, San Diego. His research interests include electrochemical sensors, and functional nanomotors. tissues and cells, notably in the brain, heart, gastrointestinal tract, vascular smooth muscles, and endothelial cells, acting as a messenger much like nitric oxide (NO) and carbon monoxide (CO). ${ }^{2-5}$ Its important roles in mammalian systems prompt us to explore a fast and sensitive detection method to monitor its concentration in biological samples for fully understanding the effects of its possible physiological and pathophysiological roles, as well as its potential therapeutic use. $^{6-8}$ Due to the widespread interest in its biological functions, detection methods for sulfide have evolved from simple colorimetric assays to the more recently used techniques, including high pressure liquid chromatography (HPLC) and gas chromatography (GC), ${ }^{9-11}$ monobromobimane (MBB), ${ }^{12-15}$ fluorescence probe, ${ }^{8}$ and electrochemical sensors (ion sensitive electrodes and polarographic $\mathrm{H}_{2} \mathrm{~S}$ sensors, etc.). ${ }^{16,17}$ Certainly, each technique has its advantages and limitations. Chromatography based methods, which have been used to

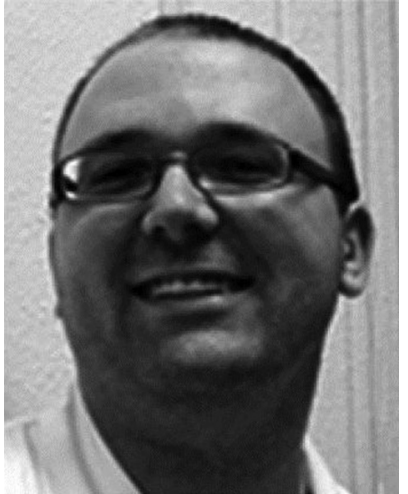

Nikki Scafa
Nikki Scafa is a research assistant at World Precision Instruments Inc. in Sarasota, FL. He graduated from the University of Florida with a bachelor's degree in chemical engineering. He performs quality control testing on sensors in the area of biosensing and tests new and prototype sensors for research applications. In the six years that he has been there, he has performed research testing to facilitate the release of sensors that measure different chemical species, including nitric oxide, hydrogen peroxide, hydrogen sulfide, and oxygen. 
measure both plasma and tissue $\mathrm{H}_{2} \mathrm{~S}$ sensitivity, however, do not have the capability of real-time measuring in biological samples and require hypoxic or anoxic conditions. ${ }^{10,11,18}$ In a typical $\mathrm{MBB}$ assay, $\mathrm{H}_{2} \mathrm{~S}$ reacts with two molecules of monobromobimane to form the fluorescent sulfide-dibimane, followed by HPLC assay with fluorescence detection. This method requires relatively expensive equipment, and its time consuming process results in unknown reactions in blood samples, thus interfering in the detection of sulfide and making real-time measurements of $\mathrm{H}_{2} \mathrm{~S}$ impossible. ${ }^{12-15}$ The methylene-blue method is one of the most commonly used spectrometric methods for measuring plasma $\mathrm{H}_{2} \mathrm{~S}$, which involves the reaction of $\mathrm{H}_{2} \mathrm{~S}$ with $N, N$-dimethyl- $p$-phenylenediamine sulfate to produce the light-absorbing methylene blue. Nevertheless, this direct method lacks sensitivity at low concentrations $(<1 \mu \mathrm{M})$ and requires long incubation periods (>30 min), making it unsuitable for continuous measurement of $\mathrm{H}_{2} \mathrm{~S}$ under real-time, physiological conditions. ${ }^{19,20}$ Some other spectroscopic methods offer high sensitivity and selectivity for $\mathrm{H}_{2} \mathrm{~S} .^{21-25}$ For example, it is noteworthy that the most recently developed sulfide-sensitive fluorescent probes enable $\mathrm{H}_{2} \mathrm{~S}$ measurement in cell and blood samples at low concentrations. ${ }^{14,26}$ In addition, the greatest limitations for fluorescent indicators (i.e. response time and sample damage) leave significant room for improvement in the future.

Chemical and biological methods with several advantages have become one of the most active areas of analytical research in recent years. Electrochemical biosensors, as one of the most common methods, have been widely used to detect biomolecules such as glucose,$^{27}$ nitric oxide, ${ }^{28,29}$ ascorbic acid, ${ }^{30}$ uric acid, ${ }^{31}$ dopamine, ${ }^{32}$ and hydrogen peroxide. ${ }^{33}$ Electrochemical biosensing is also an effective method to measure the $\mathrm{H}_{2} \mathrm{~S}$ concentration in different kinds of samples with distinct advantages of high sensitivity, high selectivity, low-detection limit, stability, long lifetime, wide linear range, fast response time, biocompatibility, reproducibility, and simple operation. ${ }^{18,34-37}$ These advantages have attracted a number of researchers to develop new electrochemical methods for determining sulfide species in inorganic and organic forms. ${ }^{18,34-37}$ The present review has made an effort to detail the most recent research on ion sensitive electrodes, polarographic $\mathrm{H}_{2} \mathrm{~S}$ sensors, and enzyme based electrodes for $\mathrm{H}_{2} \mathrm{~S}$ concentration detection in biological samples.

\section{Background perspective of $\mathrm{H}_{2} \mathrm{~S}$}

\section{1 $\mathrm{H}_{2} \mathrm{~S}$ in chemistry}

Hydrogen sulfide is a weak acid with $\mathrm{p} K_{\mathrm{a} 1}=6.6$, and $\mathrm{p} K_{\mathrm{a} 2}=$ 13.8 at $25{ }^{\circ} \mathrm{C}^{38} \mathrm{H}_{2} \mathrm{~S}$ aqueous solution is a mixture of $\mathrm{H}_{2} \mathrm{~S}$, $\mathrm{HS}^{-}$, $\mathrm{S}^{2-}$ and dissociates $\left(\mathrm{H}_{2} \mathrm{~S} \leftrightarrow \mathrm{H}^{+}+\mathrm{HS}^{-} \leftrightarrow 2 \mathrm{H}^{+}+\mathrm{S}^{2-}\right)$. However, there is only a trace of $\mathrm{S}^{2-}$ in normal biological samples $(\mathrm{pH} \sim 7)$ because $\mathrm{p} K_{\mathrm{a} 2}$ is higher than $13 . \mathrm{H}_{2} \mathrm{~S}$ is strongly harmful, toxic, and flammable when released into the atmosphere either as a pollutant from the chemical industry or as a by-product of biological activity. The electric potential between $\mathrm{H}_{2} \mathrm{~S}$ and $\mathrm{O}_{2}$ is really high, making it extremely favorable for oxidation reactions, so $\mathrm{H}_{2} \mathrm{~S}$ can be oxidized to sulfur dioxide $\left(\mathrm{SO}_{2}\right)$, sulfates, and elemental sulfur. Chemical industry oxidation $\left(\mathrm{H}_{2} \mathrm{~S}+2 \mathrm{O}_{2} \rightarrow \mathrm{SO}_{4}{ }^{2-}+2 \mathrm{H}^{+}\right)$which is catalyzed by metals or metal oxides, is one of the main sources of acid rain. Moreover, $\mathrm{H}_{2} \mathrm{~S}$ is also harmful in industrial production: fabrication of fuel cells requires the control of $\mathrm{H}_{2} \mathrm{~S}$ at ppb levels in order to extend the lifetime of the proton exchange membrane, while in the food industry, $\mathrm{H}_{2} \mathrm{~S}$ needs to be monitored at a trace level to guarantee the quality of products.

\section{2 $\mathrm{H}_{2} \mathrm{~S}$ function in a biological system}

Recent studies have established that $\mathrm{H}_{2} \mathrm{~S}$ is an important signalling molecule of comparable importance to $\mathrm{NO}$ and $\mathrm{CO}$ in

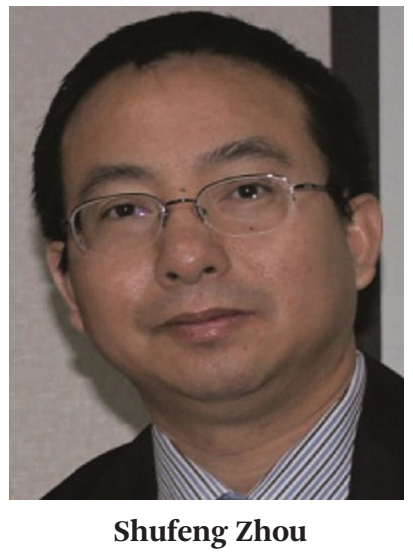

Shufeng Zhou is presently the Associate Vice President of Global Medical Development \& Associate Dean of International Research, College of Pharmacy, University of South Florida, Tampa (USF), Florida. He completed his clinical medical training in China in 1986 and obtained his PhD in 2001 from the School of Medicine, the University of Auckland, New Zealand. Dr Zhou's major research interests entail systems pharmacology, nanomedicine, pharmacokinetics, and pharmacogenomics. He has published more than 350 peer-reviewed journal papers, 18 books and book chapters. His work has been cited more than 10000 times by other colleagues. 
mammalian tissues and cells. The production of $\mathrm{H}_{2} \mathrm{~S}$ can occur via two pathways: enzymatic and non-enzymatic. Much emphasis has been placed on the enzymatic production of $\mathrm{H}_{2} \mathrm{~S}$, which is formed from cysteine by $\mathrm{H}_{2} \mathrm{~S}$ synthases, namely cystathionine $\beta$-synthase (CBS), cystathionine $\gamma$-lyase (CSE) and 3-mercaptopyruvate sulfurtransferase (MST). ${ }^{39}$ Non-enzymatic production of $\mathrm{H}_{2} \mathrm{~S}$ occurs through glutathione, inorganic and organic polysulfides, and elemental sulfur. ${ }^{18,39}$ Apart from the free state, $\mathrm{H}_{2} \mathrm{~S}$ can react with several different biochemical molecules to establish different bio-available pools, such as acid labile sulfides (Fe-S complexes and persulfides) and bound sulfide forms (polythionates, polysulfides, thiosulfate, thiosulfonates, bisorganylpolysulfanes, monoarylthio-sulfonates, and elemental sulfur). However, less is known about the catabolism of $\mathrm{H}_{2} \mathrm{~S}$ in the body. One possible catabolic pathway is the rapid oxidation to thiosulfate $\left(\mathrm{S}_{2} \mathrm{O}_{3}{ }^{2-}\right)$ by mitochondria and subsequent conversion to the stable product sulfate $\left(\mathrm{SO}_{4}{ }^{2-}\right.$ ) in cells. ${ }^{40} \mathrm{H}_{2} \mathrm{~S}$ is more soluble in lipids than in water, which makes it easier to travel into and out of cell membranes. As one of the messenger molecules throughout the body, $\mathrm{H}_{2} \mathrm{~S}$ can modulate the neuronal transmission, can relax smooth muscles, and is involved in inflammation together with NO and $\mathrm{CO}^{7}$ Several cardiovascular diseases are also related to its function in cardiovascular physiology and pathophysiology. ${ }^{41}$ Potential therapeutic uses in ischemia/reperfusion (I/R) injury have been examined extensively in the heart, brain, lungs, and liver. ${ }^{42,43} \mathrm{H}_{2} \mathrm{~S}$ produces anti-inflammatory effects in neurocytes, which may contribute to atherosclerosis by various mechanisms depending on the disease stage. ${ }^{44}$ Whereas $\mathrm{H}_{2} \mathrm{~S}$ is toxic to the human body at high levels; it may cause unconsciousness and death in humans at concentrations above 500 ppm. $^{45}$

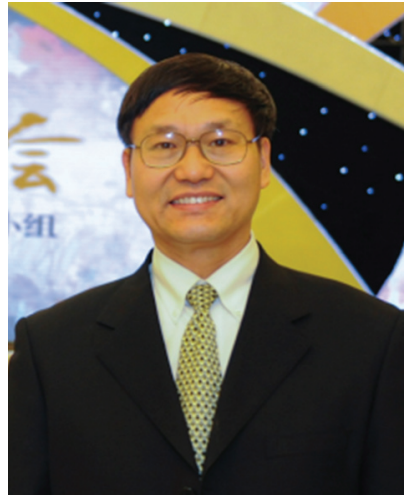

Xueji Zhang
Xueji Zhang is the national chair professor \& director of the Research Center for Bioengineering and Sensing Technology, University of Science \& Technology, Beijing, China. He obtained his Ph.D. from Wuhan University in 1994. He was a postdoc fellow at the National Institute of Chemistry, Slovenia, Swiss Federal Institute of Technology (ETH), Zurich, and New Mexico State University from 1995-1999. He has worked at World Precision Instruments Inc. USA as a Sr scientist, head of chemistry department, and vice president and Sr vice president of science respectively since 1998. His research has centered on electrochemistry, bioanalysis, micro/nanosensors, and biomedical instrumentation.

\subsection{Electrochemical oxidation of $\mathrm{H}_{2} \mathrm{~S}$}

A typical three-electrode configuration, consisting of a working electrode, a reference electrode, and a counter electrode, is employed to detect $\mathrm{H}_{2} \mathrm{~S}$ concentration from different kinds of sources. Hydrogen sulfide can be oxidized at the working electrode with the transfer of two electrons $\left(\mathrm{H}_{2} \mathrm{~S}=\mathrm{S}+2 \mathrm{H}^{+}+2 \mathrm{e}^{-}\right.$ $E^{0}=0.171 \mathrm{~V} v s . \mathrm{Ag} / \mathrm{AgCl}$ ) and produce a current. With the transfer of more electrons, it can be further oxidized into sulfite $\left(\mathrm{SO}_{3}{ }^{2-}\right)$ and sulfate $\left(\mathrm{SO}_{4}{ }^{2-}\right) \cdot{ }^{46}$ Electrochemical $\mathrm{H}_{2} \mathrm{~S}$ sensors can be divided into liquid and solid electrolyte sensors based on its electrolytes. Based on their working principles, these sensors can be further divided into amperometric and potentiometric, ${ }^{37}$ which are two of the most common techniques employed to detect $\mathrm{H}_{2} \mathrm{~S}$ concentration in biological samples. Specifically, an amperometric method can monitor the very low redox current (e.g. pA's) produced by the oxidation of $\mathrm{H}_{2} \mathrm{~S}$ over time at a fixed (poise) voltage potential. This method has a fast response time of only a few seconds, high sensitivity, and provides the quantitative measurement of minute changes in $\mathrm{H}_{2} \mathrm{~S}$ concentration.

\section{Electrochemical detection of $\mathrm{H}_{2} \mathrm{~S}$}

Electrochemical sensors have several advantages that make them an attractive method for real-time detection of $\mathrm{H}_{2} \mathrm{~S}$ in biological samples due to their high sensitivity, high selectivity, low detection limit, fast response time, miniaturization capabilities, and the fact that they do not require additional chemical reagents. Solid-electrolyte sensors (such as solidpolymer electrolyte (SPE)-Pt and metal oxide based sensor) are commonly applied for quantitative analysis of hydrogen sulfide gas in the chemical industry. ${ }^{47-49}$ Ion sensitive electrodes (ISEs) and amperometric (polarographic) $\mathrm{H}_{2} \mathrm{~S}$ sensors (PHSSs) are two well-known devices that have been applied to detect $\mathrm{H}_{2} \mathrm{~S}$ concentration in biological samples.

\subsection{Ion sensitive electrodes (ISEs) for $\mathrm{H}_{2} \mathrm{~S}$ detection}

Ion sensitive based electrodes are one of the most commonly used methods to measure concentrations of $\mathrm{H}_{2} \mathrm{~S}$ in plasma with a detection range of $1-100 \mu \mathrm{M}$. This method is easy to obtain and operate. It is sensitive towards sulfide anions and allows for dynamic detection of sulfide concentration within one minute. Common $\mathrm{Ag} / \mathrm{Ag}_{2} \mathrm{~S}$ ISEs are simply prepared by dipping a silver wire into saturated sodium sulfide solution. The silver wire slowly reacts with the $\mathrm{S}^{2-}$ ions, forming a thin and dark layer of $\mathrm{Ag}_{2} \mathrm{~S}$ on the surface of the silver wire. The $\mathrm{Ag}_{2} \mathrm{~S}$ layer can serve as a protection membrane preventing the interference of the samples. Carefully checking the electrode surface is necessary to make sure that the thin layer of $\mathrm{Ag}_{2} \mathrm{~S}$ without silver is exposed to the surface. Otherwise, there will be a loss of selectivity due to the silver portion of the electrode being responsive to redox changes in the solution. ${ }^{50}$ This method was first reported in plasma $\mathrm{H}_{2} \mathrm{~S}$ concentration measurement by Mason et al., but without the details of the procedure. $^{51}$ Khan et al. made a full detailed procedure of 
Table 1 Measurement of the concentration of $\mathrm{H}_{2} \mathrm{~S}$ by using an ISE in biological samples

\begin{tabular}{|c|c|c|c|c|}
\hline Standard & $\begin{array}{l}\text { Plasma or blood } \mathrm{H}_{2} \mathrm{~S} \\
\text { concentration }\end{array}$ & Samples & Applications & Ref. \\
\hline $\mathrm{Na}_{2} \mathrm{~S}$ & 10 & Rat blood & Sulfide oxidation & 51 \\
\hline NaHS & & Rat blood & KATP channel & 53 \\
\hline NaHS & 38 & Trout plasma & Smooth muscle & 57 \\
\hline $\mathrm{H}_{2} \mathrm{~S}$ & 34 & Human plasma & Chronic obstructive pulmonary disease & 58 \\
\hline $\mathrm{S}^{2-}$ & 51.7 & Human plasma & Coronary heart disease & 59 \\
\hline $\mathrm{H}_{2} \mathrm{~S}$ & 39.7 & Rat plasma & Balloon injury & 62 \\
\hline $\mathrm{S}^{2-}$ & 46 & Rat plasma & L-Arginine/NO pathway & 63 \\
\hline $\mathrm{H}_{2} \mathrm{~S}$ & 21 & Rat plasma & Lung injury & 64 \\
\hline $\mathrm{Na}_{2} \mathrm{~S}$ & 23.8 & Rat plasma & Metabolic function & 65 \\
\hline NaHS & 40 & Rat plasma & Hypertension & 54 \\
\hline NaHS & 90 & Rainbow trout plasma & Adrenergic stress response & 66 \\
\hline NaHS & $1.75 \mathrm{nM} \mathrm{mg}^{-1}$ & Rat cellular $\mathrm{H}_{2} \mathrm{~S}$ & Methylglyoxal function & 71 \\
\hline NaHS & & Leaf supernatant & Gasotransmitter & 72 \\
\hline \multirow[t]{2}{*}{ NaHS } & & Leaf supernatant & Autophagy, and transcriptional modulator & 73 \\
\hline & & Rat liver & Dietary restriction & 74 \\
\hline
\end{tabular}

plasma $\mathrm{H}_{2} \mathrm{~S}$ concentration measurement. ${ }^{52}$ In brief, sulfide antioxidant buffer was added into blood samples at a ratio of $1: 1$. The electrode was rinsed with distilled water and then placed in sample solutions. Next, the value was recorded when a stable reading was displayed. Finally, $\mathrm{H}_{2} \mathrm{~S}$ concentration was calculated by the standard $\mathrm{S}^{2-}$ solution. ${ }^{52}$ Based on this method, commercial sulfide sensitive electrodes (Model 9616, Orion Research, Beverly, MA) were widely used in serum $\mathrm{H}_{2} \mathrm{~S}$ concentration detection. ${ }^{53}$ Another commercial ISE, known as Arrow $\mathrm{H}_{2} \mathrm{~S}^{\mathrm{TM}}$ developed by Lazar Research Laboratories (Los Angeles, CA), is a small ion electrode. This sensor can measure volumes down to 10 microliters with a one-step sample prepperformance directly in the micro container, which obviously prevented $\mathrm{H}_{2} \mathrm{~S}$ loss from the sample and increased accuracy. In addition, unlike other methods, this micro-electrode measurement method has no known interferents and has a detection limit as low as $100 \mathrm{nM} \cdot{ }^{54}$ A variety of applications of the ISE-based $\mathrm{H}_{2} \mathrm{~S}$ sensor have been listed in Table 1. However, using $\mathrm{Ag} / \mathrm{Ag}_{2} \mathrm{~S}$ electrodes detection of $\mathrm{H}_{2} \mathrm{~S}$ has several problems, such as the requirement of an alkaline environment favoring the $\mathrm{S}^{2-}$ equilibrium, operating in a low concentration range, and maintaining the connection between the electrolyte bridge and the reference electrode. ${ }^{18,36}$ Whitfield et al. have demonstrated that $\mathrm{S}^{2-}$ levels of trout plasma and BSA placed in alkaline buffer increased by $1 \mathrm{mM}$ over a period of 12 hours, which makes its application to biological samples questionable and requires consideration of strong chemical pretreatment of samples. ${ }^{18,55,56}$ Another disadvantage of this method is the requirement for the electrode to be reconditioned and calibrated daily due to formation of $\mathrm{Ag}_{2} \mathrm{~S}$ on the electrode surface.

\subsection{Polarographic $\mathrm{H}_{2} \mathrm{~S}$ sensors (PHSSs)}

Although it is clear that $\mathrm{H}_{2} \mathrm{~S}$ plays an important physiological role in mammalian systems, the effects of $\mathrm{H}_{2} \mathrm{~S}$ under physiological conditions remain largely undefined without the benefit of real-time $\mathrm{H}_{2} \mathrm{~S}$ measurements. An amperometric $\mathrm{H}_{2} \mathrm{~S}$ sensor offers a reliable real-time method and has shown promise in detecting the concentration of $\mathrm{H}_{2} \mathrm{~S}$ in whole blood and mammalian tissues, without altering the sample as summarized in Table $2 .^{36}$ This was first developed by Jeroschewski et al., based on a standard Clark-type oxygen electrode, and used for $\mathrm{H}_{2} \mathrm{~S}$ measurement in aquatic environments with a detection limit as low as $2 \mu \mathrm{M} .^{75}$ Kraus and Doeller modified the polarographic oxygen sensor, enabling it for the real-time measurement of $\mathrm{H}_{2} \mathrm{~S}$ gas from biological samples with a lower detection limit in the nM range under anoxic conditions. ${ }^{76}$ In short, macro PHSSs $(L=25 \mathrm{~mm}, D=12 \mathrm{~mm})$ were designed originally from a polarographic oxygen sensor (POS, model 2120 , Orbisphere, Geneva, Switzerland) with platinum wires (1 and $0.5 \mathrm{~mm}$ diameter) as the anode and cathode, respectively. The PHSS housing was machined from polyether ether ketone (PEEK). The electrolyte was held in the sensor tip reservoir with a two-layer membrane made of an $\mathrm{H}_{2} \mathrm{~S}$-permeable membrane (MEM-213, $25 \mu \mathrm{m}$ thick, WPI, Inc.), cemented (Silicone Adhesive RTV 167, GE, Waterford, NY) to a $25 \mu \mathrm{m}$ thick $\mathrm{H}_{2} \mathrm{~S}$ impermeable membrane. The $\mathrm{H}_{2} \mathrm{~S}$-permeable membrane allows the permeation of $\mathrm{H}_{2} \mathrm{~S}$ through a hole $(D=0.5 \mathrm{~mm})$ into an alkaline $\mathrm{K}_{3} \mathrm{Fe}(\mathrm{CN})_{6}$ internal electrolyte solution. $\mathrm{H}_{2} \mathrm{~S}$ was dissociated into $\mathrm{HS}^{-}$after crossing the permeable membrane and then chemically oxidized to S0 while simultaneously reducing $\mathrm{Fe}(\mathrm{CN})_{6}{ }^{3-}$ to $\mathrm{Fe}(\mathrm{CN})_{6}{ }^{4-}$. The $\mathrm{Fe}(\mathrm{CN})_{6}{ }^{4-}$ is then electroche- 
Table 2 Measurement of the concentration of $\mathrm{H}_{2} \mathrm{~S}$ by using a PHSS in biological samples

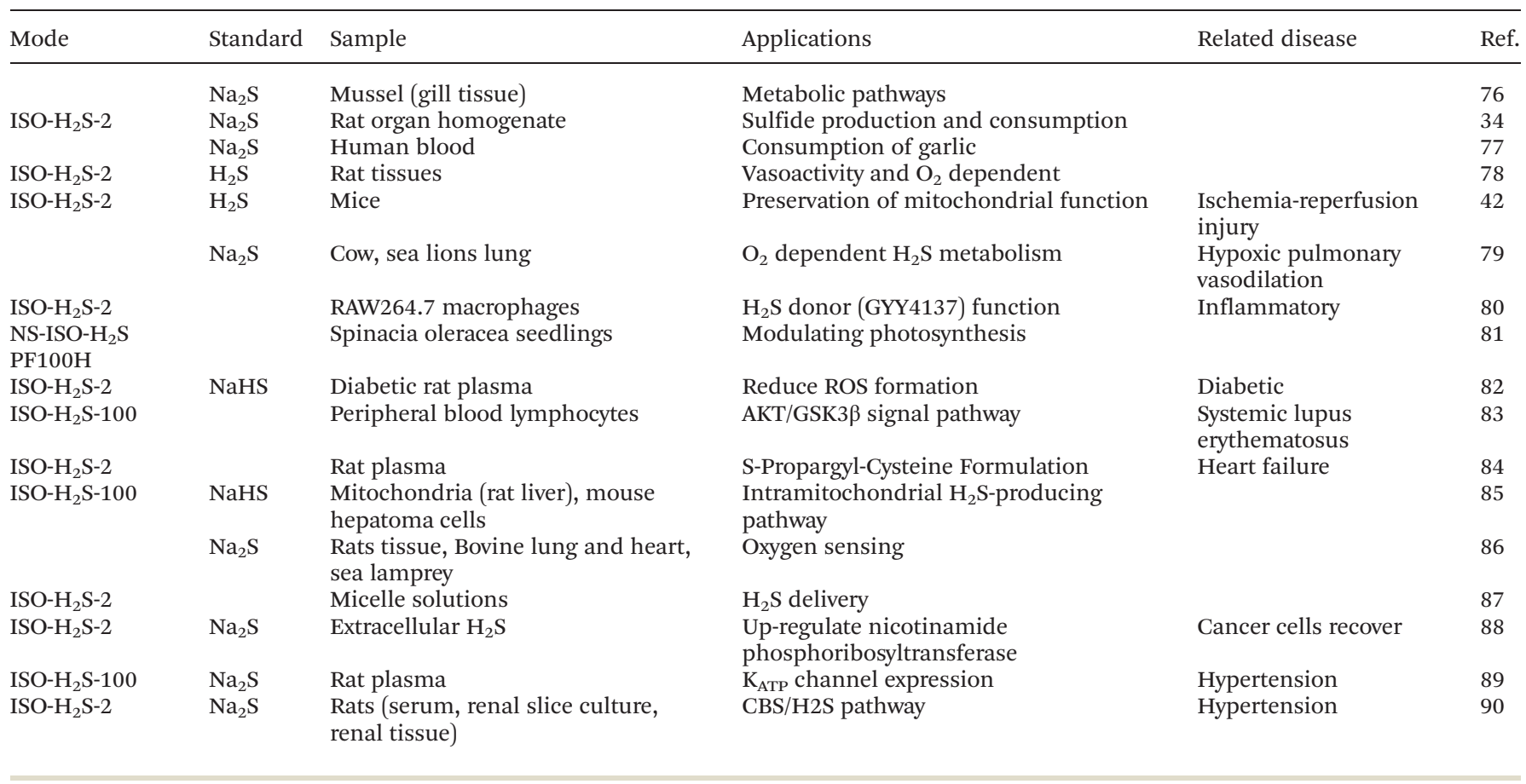

mically oxidized back to $\mathrm{Fe}(\mathrm{CN})_{6}{ }^{3-}(0.1-0.2 \mathrm{~V} v s$. SCE $)$ on the surface of the platinum electrode, producing a current proportional to $\mathrm{H}_{2} \mathrm{~S}$ concentration in biological samples. Kraus's group developed another miniature PHSS based on the original design of the macro one. This miniature PHSS utilizes a cylindrical platinum anode that was electrically insulated along the side from a coiled platinum cathode. The core was housed in a $2 \mathrm{~mm}$ outside diameter stainless steel cylindrical sleeve and a $25 \mu \mathrm{m}$ thick $\mathrm{H}_{2} \mathrm{~S}$-permeable membrane to cover the tip. The reservoir between the sleeve and core was filled with the ferricyanide electrolyte solution. The end of the sensor, contained within the sleeve $(L=50 \mathrm{~mm})$, was fitted into a port of a PEEK stopper (contained two sensor ports and an injection port). Whitfield $e t$ al. made further modifications of PHSS. In brief, this design of the PHSS consisted of a heatsealed platinum wire and a platinum wire cathode coiled around the capillary tube. The whole assembly was then inserted into an outer glass case containing a solution of $50 \mathrm{mM}$ potassium ferricyanide in $\mathrm{pH} 10,0.5 \mathrm{M}$ sodium carbonate buffer. An O-ring was seated in a groove in the outer glass case to hold in place a $25 \mu \mathrm{m}$ thick silicone polycarbonate membrane (SSP-M213; Specialty Silicone Products, Inc., Ballston Spa NY). The $2 \mathrm{~mm}$ diameter PHSS (response time $<5 \mathrm{~s}$, detection limit $<5 \mathrm{nM}$, sensitivity $=2 \mathrm{pA} \mathrm{nM}^{-1}$ ) described above is also available from World Precision Instruments (model ISO- $\mathrm{H}_{2} \mathrm{~S}-2$, Sarasota, FL, USA), which was connected to a multichannel Free Radical Analyzer (TBR4100,WPI Inc., Sarasota, FL, USA) ${ }^{34}$ Moreover, this company developed an ultramicro PHSS (ISO- $\mathrm{H}_{2} \mathrm{~S}-100-\mathrm{CXX}$, WPI, Inc., Sarasota, FL, USA) with a diameter of only $100 \mu \mathrm{m}$, which can obviously reduce the damage of the samples and offers several advantages, including requiring no sleeves or filling solutions, durability for long-term use, rapid response time, and a bigger linear range. Compared to an ISE based $\mathrm{H}_{2} \mathrm{~S}$ sensor, this type of sensor detects $\mathrm{H}_{2} \mathrm{~S}$ without an external electrical potential, has a simple structure, good reproducibility, a short response time, and less containment of noble metals. However, a greater disadvantage of the liquid electrolyte sensors is that they leak easily, are prone to dry up, and have large residual current due to impurities in the solution.

\subsection{Enzyme based electrochemical $\mathrm{H}_{2} \mathrm{~S}$ biosensors}

Enzyme-based electrochemical biosensors have become more practical than other electrochemical detection methods due to their high sensitivity and selectivity in recent years. An enzyme-inhibition biosensor depends on both the concentration of the target analyte in the sample and the type of inhibited enzyme, which are commonly used for measurement of the concentration of inhibitory compounds. ${ }^{91}$ The common design of this type of $\mathrm{H}_{2} \mathrm{~S}$ sensor involves an electrochemical transducer and an enzyme as the recognition element. Early in the 1990s, cytochrome oxidase-based inhibited enzyme electrodes were studied by researchers with a detection limit concentration of $\mathrm{H}_{2} \mathrm{~S}$ down to $1 \mathrm{ppm}$ in the gas phase. However, this electrode responds to other target analytes (HCN, and azide ion), making its application to biological samples questionable and developing a need for chemical pretreatment of samples. ${ }^{92}$ Horseradish peroxidase is stable and has a number of potential inhibitors in homogeneous solutions. Therefore, it has been widely used as an inhibited enzyme electrode by researchers for $\mathrm{H}_{2} \mathrm{~S}$ detection. Colloidal gold-immobilized horseradish peroxidase for $\mathrm{H}_{2} \mathrm{~S}$ detection has been reported by 
Zhao et al., but it seems more sensitive to cyanide and thiourea than sulfide. In addition, its detection limit is only $8 \mu \mathrm{M}$ which is not enough for analyzing environmental samples. ${ }^{93}$ Yang et al. developed an amperometric horseradish peroxidase inhibition $\mathrm{H}_{2} \mathrm{~S}$ biosensor based on a thiolate self-assembled monolayer (SAM), which has a much lower detection limit $(0.3 \mu \mathrm{M})$. Nevertheless, the selectivity of SAM-based biosensors is poor for many common cations which greatly limits their application for analysis of environmental water. ${ }^{94}$ Based on the method Yang et al. developed, Liu et al. reported a multilayer film-modified biosensor via layer-by-layer (LBL) biospecific binding of concanavalin A and horseradish peroxidase on the surface of the gold electrode, which shows no interference of the common anions and cations in environmental water. ${ }^{95}$ Coprinus cinereus peroxidase immobilized on a screen printed electrode was reported by Savizi et al. This was used as an enzyme inhibition $\mathrm{H}_{2} \mathrm{~S}$ biosensor which has a detection limit of $0.3 \mu \mathrm{m}$ (linear response in the range of 1.09-16.3 $\mu \mathrm{M}$ ) and a response time of $43 \mathrm{s.}^{47}$ Another enzyme inhibition $\mathrm{H}_{2} \mathrm{~S}$ biosensor, ascorbate oxidase, was immobilized on a Clark electrode and protected with a nylon membrane. This electrode can detect $\mathrm{H}_{2} \mathrm{~S}$ at a low detection limit and prevent interference of main cations and anions. ${ }^{96}$ The enzyme based $\mathrm{H}_{2} \mathrm{~S}$ biosensor mentioned above shows great advantages of selectivity and sensitivity. However, one of the most regrettable characteristics of the enzyme inhibition-based biosensors is the different inhibition degrees caused by different inhibitors. Moreover, this kind of sensor also highly depends on the $\mathrm{pH}$ concentration due to its inhibition on the activity of enzyme, making it difficult to apply to in vivo $\mathrm{H}_{2} \mathrm{~S}$ detection.

\section{Calibration of the $\mathrm{H}_{2} \mathrm{~S}$ electrode}

Calibration of an $\mathrm{H}_{2} \mathrm{~S}$ sensor is important in order to ensure the exact experimental results. In general, the PHSS was calibrated with stepwise additions of $\mathrm{H}_{2} \mathrm{~S}$ stock solution at the $\mathrm{pH}$ and temperature of the subsequent experiment. Detection of the $\mathrm{H}_{2} \mathrm{~S}$ content in the sample was calculated from the calibration curve of current (pA) vs. concentration of $\mathrm{H}_{2} \mathrm{~S} \cdot \mathrm{H}_{2} \mathrm{~S}$ stock solution was freshly prepared by directly bubbling distilled water with pure $\mathrm{H}_{2} \mathrm{~S}$ gas (Matheson, Newark, CA) to make the saturated $\mathrm{H}_{2} \mathrm{~S}$ solution $\left(0.09 \mathrm{M}\right.$ at $\left.30^{\circ} \mathrm{C}\right)$. The $\mathrm{H}_{2} \mathrm{~S}$ stock solution was diluted to different concentrations into cell culture medium and the $\mathrm{pH}$ of the medium was adjusted to 7.4. Stock solutions of $\mathrm{H}_{2} \mathrm{~S}$ can also be conveniently made with the salt, $\mathrm{Na}_{2} \mathrm{~S} \cdot 9 \mathrm{H}_{2} \mathrm{O}$ (Sigma-Aldrich). This method avoids the need for a special gas-handling apparatus required for pure $\mathrm{H}_{2} \mathrm{~S}$ gas, and the additional micromolar sodium, as $\mathrm{Na}_{2} \mathrm{~S}$, dissociates to form $\mathrm{Na}^{+}$and the three sulfide species $\mathrm{H}_{2} \mathrm{~S}, \mathrm{HS}^{-}$ and $\mathrm{S}^{2-}$ in $\mathrm{pH}$ dependent ratios. ${ }^{76}$ The calibration of the ISE based $\mathrm{H}_{2} \mathrm{~S}$ sensor should be carried out daily. Four $10 \mathrm{ml}$ aliquots of $10 \mathrm{ppm} \mathrm{S}^{2-}$ standard solution were pipetted into $50 \mathrm{ml}$ beakers. Electrodes were immersed in the solution and then measurements were recorded once the reading became stable (approx. $1 \mathrm{~min}$ ). Then, $1 \mathrm{ml} 100 \mathrm{ppm} \mathrm{S}^{2-}$ standard solu- tion was immediately added and the second reading was recorded after $1 \mathrm{~min}$. Finally, the resulting difference in the potential was used to calculate the exact concentration of the standardizing solution by applying the Nernst equation. ${ }^{52}$

\section{Characterization of $\mathrm{H}_{2} \mathrm{~S}$ electrodes}

An excellent $\mathrm{H}_{2} \mathrm{~S}$ electrochemical sensor can be characterized by high sensitivity, high selectivity, low-detection limit, stability, long lifetime, wide linear range, fast response time, biocompatibility, and reproducibility. ${ }^{17}$ The sensitivity of the electrochemical $\mathrm{H}_{2} \mathrm{~S}$ sensor depends on the reactive surface, electrode material, the assisted membrane material, and $\mathrm{pH}$ of the solution. The measurement of the $\mathrm{S}^{2-}$ form of sulfide species using an ISE-based $\mathrm{H}_{2} \mathrm{~S}$ sensor requires an alkaline environment. A PHSS is also highly dependent on solution $\mathrm{pH}$, and has a sensitivity of $5.5 \mathrm{nA} \mu \mathrm{M}^{-1}$ at $\mathrm{pH}=6$ where $\mathrm{H}_{2} \mathrm{~S}$ is approximately $90 \%$ of the total sulfide. ${ }^{17}$ However, high sensitivity does not imply a low detection limit; the low detection limit of the sensor can make it more practical for a wide variety of samples. The detection limit of a PHSS is dependent on the $\mathrm{pH}$, in anoxic $10 \mathrm{mM}$ PBS at $\mathrm{pH} 7.0$ and $37^{\circ} \mathrm{C}$ it was near $10 \mathrm{nM}$, while the detection limit of an ISE sensor could be $100 \mathrm{nM}$; both thesensors are sufficient for biological applications. $^{34,55}$ Selectivity is usually controlled by the applied voltage and the selective layer provided by each kind of $\mathrm{H}_{2} \mathrm{~S}$ sensor. The acceptable voltage can reduce the noise signal level of other biological matrices oxidized on the electrode. An $\mathrm{Ag} / \mathrm{Ag}_{2} \mathrm{~S}$ ISE $\mathrm{H}_{2} \mathrm{~S}$ electrode with a permissible $\mathrm{Ag}_{2} \mathrm{~S}$ membrane specifically allows $\mathrm{S}^{2-}$ ions to migrate across the thin layer which can effectively reduce interference from other biological matrices. The membranes of the PHSS are cemented together with silicone cement, which can prevent the interference from $\mathrm{O}^{2-}$, NO, and millimolar concentrations of hydrogen peroxide, sulfite, and sulfate. An enzyme-based $\mathrm{H}_{2} \mathrm{~S}$ sensor with a special inhibited enzyme as the recognition element can make it just respond to $\mathrm{H}_{2} \mathrm{~S} .{ }^{17}$ Linear range and response time are important before performing any measurement for accurate results, as a wide linear range means that the sensor can be applied in additional sample detection. A typical commercially available $\mathrm{H}_{2} \mathrm{~S}$ sensor from World Precision Instruments (PHSS, Sarasota, FL, USA) has a concentration range from 0.3 to $200 \mu \mathrm{M}$, which is much wider than that of ISE and enzyme based $\mathrm{H}_{2} \mathrm{~S}$ sensors. However, the amperometric signal loses linearity at high $\mathrm{H}_{2} \mathrm{~S}$ concentrations. The PHSS typically takes less than $10 \mathrm{~s}$ to reach $90 \%$ of the new signal in response to $\mathrm{H}_{2} \mathrm{~S}$ changes by addition or removal. Sensor stability, long lifetime, and reproducibility are important parameters in order to make sure that there is no sensitivity loss. PHSS has a loss of $\mathrm{H}_{2} \mathrm{~S}$ sensitivity and an elevated background current after several calibrations compared to earlier ones, these sensors require membrane or electrolyte replacement to ensure their sensitivity. To determine the precision of the PHSS response, 5 to 10 successive $2 \mu \mathrm{L}$ injections of a $10 \mathrm{mM}$ anoxic stock were made into a $2 \mathrm{~mL}$ anoxic chamber at $\mathrm{pH} 7.3$ and $37^{\circ} \mathrm{C}$, yield- 
ing $10 \mu \mathrm{M} \mathrm{H}_{2} \mathrm{~S}$ at each step, these stepwise injections produced a stepwise increase in current that differed by less than $\pm 2 \%$ for each injection. Response accuracy was determined by periodically sampling the chamber solution and determining the $\mathrm{H}_{2} \mathrm{~S}$ concentration with 2-PDS. Calibration of the PHSS was within $\pm 1 \%$ of the 2-PDS assay. Biocompatibility is also extremely important when measuring $\mathrm{H}_{2} \mathrm{~S}$ in vivo; the reactivity between the tissue and the electrochemical components must be minimal in order to verify there is no contribution to tissue inflammation. Since the PHSS electrochemical components are separated from sample solution by a selective membrane, there is no indication of altered biological processes.

\section{Biological application of $\mathrm{H}_{2} \mathrm{~S}$ electrochemical sensors}

Detection of sulfide in biosamples has gained significant attention from analytical and biological applications; currently, several techniques have been used to measure $\mathrm{H}_{2} \mathrm{~S}$ concentration in biological samples and biological sources like blood, serum, tissue, and breath. ${ }^{18}$ The continuous refinement of these techniques has improved detection specificity and lowered threshold limitations. An electrochemical method is still an effective and fast way to measure $\mathrm{H}_{2} \mathrm{~S}$ and its derivatives in biological samples.

\subsection{Electrochemical detection of $\mathrm{H}_{2} \mathrm{~S}$ in plasma and blood}

Detection of $\mathrm{H}_{2} \mathrm{~S}$ in plasma (or blood) has significantly enhanced the understanding of pathophysiological conditions and predicted clinical outcomes. ${ }^{36}$ Sulfide species exist with an approximate ratio of $20 \% \mathrm{H}_{2} \mathrm{~S}, 80 \% \mathrm{HS}^{-}$, and $0 \% \mathrm{~S}^{2-}$ under physiological conditions at $37{ }^{\circ} \mathrm{C}$ and $\mathrm{pH}$ 7.4. Similar to NO and $\mathrm{CO}, \mathrm{H}_{2} \mathrm{~S}$ is lipophilic and permeates plasma membranes freely. ${ }^{19}$ Almost all studies reported that sulfide concentration in plasma (or blood) was between 10 and $300 \mu \mathrm{M}$ by using the MBB methods, fluorescence probes, or ISE based methods. ${ }^{37}$ However, $\mathrm{MBB}$ and fluorescence methods require practically irreversible derivative reactions and take free sulfide out of the sample, which induces liberating sulfide from some of the reversibly bound sulfide complexes. An ISE $\mathrm{H}_{2} \mathrm{~S}$ sensor is the most common method employed in plasma $\mathrm{H}_{2} \mathrm{~S}$ detection, which was first reported in the detection of rat plasma $\mathrm{H}_{2} \mathrm{~S}$ concentration to study the role of sulphide and sulphide oxidation in the copper molybdenum antagonism in $1987 .{ }^{51}$ Khan et al. made a full detailed procedure to rapidly estimate $\mathrm{H}_{2} \mathrm{~S}$ concentration in blood using a sulfide ion electrode (Model 94-16A). ${ }^{52}$ With the properties of great availability and easy operation, ISE $\mathrm{H}_{2} \mathrm{~S}$ electrochemical sensors have been widely used to detect plasma (or blood) $\mathrm{H}_{2} \mathrm{~S}$ concentration in rat or trout blood to study its biological function as shown in Table 1. However, one of the major problems that existed in detection of sulfide in plasma (or blood) is to overcome the interference of other thiol species (GSH, protein cys derivatives etc.). Therefore, relatively high blood sulfide concentrations were detected using ISE based $\mathrm{H}_{2} \mathrm{~S}$ sensors because the required alkaline condition of these sensors released some sulfide from a proposed sulfide-biomolecule. ${ }^{97}$ Free blood sulfide levels are much lower than the total species of sulfide. In order to overcome interference of biomolecules and other problems that ISE $\mathrm{H}_{2} \mathrm{~S}$ sensors face, the PHSS was developed with a sulfide-selective membrane to protect the electrode material from sample solution (section 3.2). Olson's research reported that the ISE may not accurately measure free sulfide in the plasma due to its rapid consumption by blood. ${ }^{56}$ Furthermore, $\mathrm{H}_{2} \mathrm{~S}$ consumption was also $\mathrm{O}_{2}$ dependent which was governed by the balance between constitutive production and oxidation. ${ }^{56}$ Wintner $e t$ al. also detected low free sulfide levels in animal blood using the MBB method; they measured a similar rate of added sulfide loss in human plasma samples with the MBB method and a polarographic sensor. ${ }^{13}$

\subsection{Electrochemical detection of $\mathrm{H}_{2} \mathrm{~S}$ in tissues and mitochondria}

In order to better understand the biological roles of sulfide, it is necessary to build robust technologies that allow dynamic detection of endogenous sulfide in organs, tissues, or in vivo. However, dynamic measurements of sulfide in tissue samples are more problematic than that in the plasma (or blood) due to continuous enzymatic sulfide production and consumption processes. PHSSs, fluorescent probes, and MBB methods are shown to be able to detect sulfide levels in organs and tissues. Among these three methods, PHSS is well documented and is a reliable method to detect $\mathrm{H}_{2} \mathrm{~S}$ levels in tissues or organs as reported by Kraus's groups and the Olson laboratory. ${ }^{34,76,98}$ These sensors can be employed for real-time free $\mathrm{H}_{2} \mathrm{~S}$ detection with a low detection limit of $10 \mathrm{nM}$, and with great advantages of good reproducibility, short response, and a long linear range during detection without significant damage to the samples (section 3.2). With this approach, the production of $\mathrm{H}_{2} \mathrm{~S}$ was found in almost every organ system, such as trout gill and heart, bovine heart and lung, and rat and seal lung. ${ }^{17,18,34,76,78}$ In short, the detection of $\mathrm{H}_{2} \mathrm{~S}$ production using a PHSS in animal organ homogenate (or cells) was demonstrated by adding the substrate L-cysteine (L-cys) and the cofactor pyridoxal phosphate (PLP) for the enzymes cystathionine $\beta$-synthase (CBS) and cystathionine $\gamma$ lyase (CGL). These were used to dilute homogenate supernatant in a respirometer chamber using $5 \mu \mathrm{M} \mathrm{O}_{2}$, and the rise in the PHSS signal was recorded on a periodic basis. $\mathrm{H}_{2} \mathrm{~S}$ production rate was determined at the initial steepest slope of each trace. Recent studies on $\mathrm{H}_{2} \mathrm{~S}$ function suggested that the metabolism of $\mathrm{H}_{2} \mathrm{~S}$ could serve as an oxygen sensor in many cell types in various species. PHSS provided the first direct measurements showing that there is an inverse relationship between $\mathrm{O}_{2}$ and $\mathrm{H}_{2} \mathrm{~S}$, thus making it a potential oxygen sensor for both the pulmonary and systemic systems. ${ }^{18,56,98-100}$ The detection of $\mathrm{H}_{2} \mathrm{~S}$ consumption was exhibited by mitochondria isolated from the animal tissues (an inhabitant of sulfide-rich intertidal sediment) in an $\mathrm{O}_{2}{ }^{-}$dependent manner. Under air-equilibrated conditions, it was observed that mitochondrial $\mathrm{H}_{2} \mathrm{~S}$ consumption led to simultaneous increase in $\mathrm{O}_{2}$ consumption, causing 
some investigators to use $\mathrm{H}_{2} \mathrm{~S}$-stimulated $\mathrm{O}_{2}$ consumption as an indirect and largely qualitative measure of $\mathrm{H}_{2} \mathrm{~S}$ consumption. Using the PHSS to measure $\mathrm{H}_{2} \mathrm{~S}$ consumption as well as $\mathrm{O}_{2}$ consumption provided a dynamic metabolic stoichiometry of $\mathrm{H}_{2} \mathrm{~S}$ to $\mathrm{O}_{2}$ consumption; this demonstrated that $\mathrm{H}_{2} \mathrm{~S}$ can be consumed in the absence of $\mathrm{O}_{2}$. This detailed assessment of mitochondrial $\mathrm{H}_{2} \mathrm{~S}$ metabolism provided evidence of specific enzymatic steps and insight into mammalian $\mathrm{H}_{2} \mathrm{~S}$ metabolism.

\section{3. $\quad \mathrm{H}_{2} \mathrm{~S}$ in modulation of plant physiological processes}

$\mathrm{H}_{2} \mathrm{~S}$ is not just emerging as a third messenger molecule after nitric oxide (NO) and carbon monoxide (CO) involvement in modulation of physiological processes in animals systems, ${ }^{2-5}$ the role of $\mathrm{H}_{2} \mathrm{~S}$ metabolism in a plant system has also attracted attention in recent years. The positive effect of $\mathrm{H}_{2} \mathrm{~S}$ is also being identified as it is an important endogenous signalling molecule or bioregulator involved in many vital aspects of plant growth and responses against abiotic stresses. ${ }^{101,102}$ However, the metabolic pathways of $\mathrm{H}_{2} \mathrm{~S}$ at different developmental stages of plants under various environmental perturbations is unclear. The electrochemical method with several advantages has become an important detection method to explore the $\mathrm{H}_{2} \mathrm{~S}$ physiological processes in plants in recent years. Chen et al. used an electrochemical method (WPI, Inc., Sarasota, FL, USA) to detect the $\mathrm{H}_{2} \mathrm{~S}$ in spinacia oleracea seedlings, which provides an effective way to understand its further roles in physiological processes of photosynthesis such as promoting chloroplast biogenesis, photosynthetic enzyme expression, and thiol redox modification. ${ }^{81}$ Garcia-Mata et al. measured endogenous $\mathrm{H}_{2} \mathrm{~S}$ in leaf supernatant using a micro sulfide ion electrode (LIS-146AGSCM, Lazar Research Laboratories, Los Angeles, CA, USA) to study its functions of stomatal closure and participation in an ATP-binding cassette dependent signaling in guard cells. ${ }^{72}$ This method was also reported by Alvarez et al. to understand its specific role of sulfide as a general repressor of autophagy and a transcriptional modulator in Arabidopsis. ${ }^{73}$

\subsection{Electrochemical detection of $\mathrm{H}_{2} \mathrm{~S}$ for diagnoses and clinical therapeutic uses}

The ultimate purpose of our study of $\mathrm{H}_{2} \mathrm{~S}$ metabolism in bacteria, plants, invertebrates, and fungi is to evaluate our understanding of the important role of $\mathrm{H}_{2} \mathrm{~S}$ in regulating human body function. Directly measuring $\mathrm{H}_{2} \mathrm{~S}$ concentration in human plasma (or tissue) provides an effective way to explore its biological role and its potential therapeutic uses. Once a statistically significant difference between patients and normal control subjects is observed, we can conclude that $\mathrm{H}_{2} \mathrm{~S}$ can be used as a biomarker for treatment decisions. ${ }^{36,39}$ An electrochemical $\mathrm{H}_{2} \mathrm{~S}$ sensor is a fast and effective method to detect $\mathrm{H}_{2} \mathrm{~S}$ in human plasma in order to explore the relationship between $\mathrm{H}_{2} \mathrm{~S}$ concentration and several diseases such as chronic obstructive pulmonary disease, coronary heart disease, hypertension, etc. Significantly higher $\mathrm{H}_{2} \mathrm{~S}$ concentration in serum was observed in patients with stable chronic obstructive pulmonary disease (COPD) than patients with acute exacer- bation of COPD using an ISE $\mathrm{H}_{2} \mathrm{~S}$ sensor (Model 9616, Orion Research, Beverly, MA). ${ }^{58,103}$ In addition, the study of agematched control objects suggested that $\mathrm{H}_{2} \mathrm{~S}$ can be used as a surrogate marker with the need for antibiotics. ${ }^{58,68,103}$ A lower plasma $\mathrm{H}_{2} \mathrm{~S}$ concentration was observed in coronary heart disease (CHD) patients compared with angiographically normal control subjects by measuring $\mathrm{H}_{2} \mathrm{~S}$ concentration in 40 patients with CHD and 17 angiographically normal patients using a sulfide-sensitive electrode. ${ }^{59} \mathrm{H}_{2} \mathrm{~S}$ concentration was also reported related to essential hypertension; metabolic imbalance of homocysteine (Hcy) was markedly increased and the final product of this pathway (plasma $\mathrm{H}_{2} \mathrm{~S}$ ) was significantly decreased in hypertensive children compared with normal subjects using an ionic meter (PXS-270, Shanghai Leici, China). ${ }^{61,104}$ Zhang et al. explored the predictive value of plasma $\mathrm{H}_{2} \mathrm{~S}$ in differentiating between vasovagal syncope (VVS) and postural orthostatic tachycardia syndrome (POTS) in children (PXS-270, Shanghai Leici, China). Plasma $\mathrm{H}_{2} \mathrm{~S}$ levels were significantly higher in children with VVS and POTS; the increased erythrocyte $\mathrm{H}_{2} \mathrm{~S}$ production may be involved in the pathogenesis of VVS in children. ${ }^{105,106}$ Han et al. found that the abnormal activation of the AKT/GSK3 $\beta$ signal pathway in lymphocytes from systemic lupus erythematosus (SLE) patients plays an important role in the pathogenesis of the disease (ISO- $\mathrm{H}_{2} \mathrm{~S}-100, \mathrm{WPI}$ ). Benavides et al. explored human RBCs converting garlic-derived organic polysulfides into $\mathrm{H}_{2} \mathrm{~S}$ (measured in real time using a novel polarographic $\mathrm{H}_{2} \mathrm{~S}$ sensor), suggesting that the major beneficial effects (cardiovascular diseases etc.) of garlic rich diets are mediated by the biological production of $\mathrm{H}_{2} \mathrm{~S}$ from garlicderived organic polysulfides. ${ }^{77}$ All the evidence has indicated that electrochemical detection is becoming a leading method to detect $\mathrm{H}_{2} \mathrm{~S}$ for diagnoses and clinical therapeutic uses.

\section{Conclusions}

The enormous activity in the field of $\mathrm{H}_{2} \mathrm{~S}$ biosensors is a reflection of the major clinical importance of this topic. An electrochemical method provides an effective, direct, and responsive real-time detection of the concentration of $\mathrm{H}_{2} \mathrm{~S}$ without significant damage to living tissue. This approach is suitable for realtime detection of the concentration of $\mathrm{H}_{2} \mathrm{~S}$ in different kinds of biological samples, and has significantly enhanced the understanding of $\mathrm{H}_{2} \mathrm{~S}$ physiology functions. As researchers continue to unravel the complex biological roles of $\mathrm{H}_{2} \mathrm{~S}$ and develop therapies based on $\mathrm{H}_{2} \mathrm{~S}$, the need for highly sensitive, highly selective, reproducible, biocompatible, and accurate $\mathrm{H}_{2} \mathrm{~S}$ measurement devices will increase in the future. Finally, the increasing clarification regarding $\mathrm{H}_{2} \mathrm{~S}$ in cells and tissues will lead to a better understanding of its role in the biological system. Due to the unique properties of electrochemical $\mathrm{H}_{2} \mathrm{~S}$, the future of $\mathrm{H}_{2} \mathrm{~S}$ pathophysiology and chemical biology will be much clearer, and more research should be devoted to the detection of $\mathrm{H}_{2} \mathrm{~S}$ in blood and tissues to meet the increasing requirement of in vivo studies and clinical diagnoses. 


\section{Acknowledgements}

The work is supported by the National Natural Science Foundation of China (NSFC Grant No. 21475009, 21475008, 21175140, 21073203, 2127007, 21275017), the Fundamental Research Funds for the Central Universities (FRF-TP-15-014A3) and Beijing Higher Education Young Elite Teacher Project (YETP0424). The authors would like to express their sincere appreciation to the Deanship of Scientific Research at King Saud University for its funding of this research through the Research Group Project No. PRG-1436-011.

\section{Notes and references}

1 V. Lantto and J. Mizsei, Sens. Actuators, B, 1991, 5, 21-25.

2 H. Kimura, Mol. Neurobiol., 2002, 26, 13-19.

3 D. Boehning and S. H. Snyder, Annu. Rev. Neurosci., 2003, 26, 105-131.

4 K. Abe and H. Kimura, J. Neurosci., 1996, 16, 1066-1071.

5 R. Hosoki, N. Matsuki and H. Kimura, Biochem. Biophys. Res. Commun., 1997, 237, 527-531.

6 C. Szabo, Nat. Rev. Drug Discovery, 2007, 6, 917-935.

7 H. Kimura, Amino Acids, 2011, 41, 113-121.

8 Y. Zhao, T. D. Biggs and M. Xian, Chem. Commun., 2014, 50, 11788-11805.

9 T. Ubuka, J. Chromatogr. Biomed. Appl., 2002, 781, 227249.

10 J. Furne, A. Saeed and M. D. Levitt, Am. J. Physiol.: Regul., Integr. Comp. Physiol., 2008, 295, R1479-R1485.

11 M. D. Levitt, M. S. Abdel-Rehim and J. Furne, Antioxid. Redox Signaling, 2011, 15, 373-378.

12 X. Shen, C. B. Pattillo, S. Pardue, S. C. Bir, R. Wang and C. G. Kevil, Free Radicals Biol. Med., 2011, 50, 1021-1031.

13 E. A. Wintner, T. L. Deckwerth, W. Langston, A. Bengtsson, D. Leviten, P. Hill, M. A. Insko, R. Dumpit, E. VandenEkart, C. F. Toombs and C. Szabo, Br. J. Pharmacol., 2010, 160, 941-957.

14 M. Nishida, T. Sawa, N. Kitajima, K. Ono, H. Inoue, H. Ihara, H. Motohashi, M. Yamamoto, M. Suematsu, H. Kurose, A. van der Vliet, B. A. Freeman, T. Shibata, K. Uchida, Y. Kumagai and T. Akaike, Nat. Chem. Biol., 2012, 8, 714-724.

15 X. Shen, G. K. Kolluru, S. Yuan and C. G. Kevil, in Methods Enzymol, ed. C. Enrique and P. Lester, Academic Press, 2015, vol. 554, pp. 31-45.

16 X. Hu and B. Mutus, Rev. Anal. Chem., 2013, 32, 247-256.

17 D. W. Kraus, J. E. Doeller and X. Zhang, in Electrochemical Sensors, Biosensors and their Biomedical Applications, ed. J. Wang, X. Zhang and J. Huangxian, Academic Press, San Diego, 2008, pp. 213-235.

18 G. K. Kolluru, X. Shen, S. C. Bir and C. G. Kevil, Nitric Oxide, 2013, 35, 5-20.

19 K. R. Olson, Biochim. Biophys. Acta, 2009, 1787, 856863.

20 K. R. Olson, Antioxid. Redox Signaling, 2012, 17, 32-44.
21 A. R. Lippert, E. J. New and C. J. Chang, J. Am. Chem. Soc., 2011, 133, 10078-10080.

22 C. Liu, J. Pan, S. Li, Y. Zhao, L. Y. Wu, C. E. Berkman, A. R. Whorton and M. Xian, Angew. Chem., Int. Ed., 2011, 50, 10327-10329.

23 H. Peng, Y. Cheng, C. Dai, A. L. King, B. L. Predmore, D. J. Lefer and B. Wang, Angew. Chem., Int. Ed., 2011, 50, 9672-9675.

24 Y. Qian, J. Karpus, O. Kabil, S. Y. Zhang, H. L. Zhu, R. Banerjee, J. Zhao and C. He, Nat. Commun., 2011, 2, 495.

25 K. Sasakura, K. Hanaoka, N. Shibuya, Y. Mikami, Y. Kimura, T. Komatsu, T. Ueno, T. Terai, H. Kimura and T. Nagano, J. Am. Chem. Soc., 2011, 133, 18003-18005.

26 V. S. Lin, W. Chen, M. Xian and C. J. Chang, Chem. Soc. Rev., 2015, 44, 4596-4618.

27 J. Wang, Chem. Rev., 2008, 108, 814-825.

28 T. Xu, N. Scafa, L.-P. Xu, L. Su, C. Li, S. Zhou, Y. Liu and X. Zhang, Electroanalysis, 2014, 26, 449-468.

29 F. Bedioui and S. Griveau, Electroanalysis, 2013, 25, 587600.

30 A. Malinauskas, R. Garjonyt, R. Mazeikien and I. Jureviciut, Talanta, 2004, 64, 121-129.

31 D. Lakshmi, M. J. Whitcombe, F. Davis, P. S. Sharma and B. B. Prasad, Electroanalysis, 2011, 23, 305-320.

32 M. K. Zachek, A. Hermans, R. M. Wightman and G. S. McCarty, J. Electroanal. Chem., 2008, 614, 113-120.

33 W. Chen, S. Cai, Q. Q. Ren, W. Wen and Y. D. Zhao, Analyst, 2012, 137, 49-58.

34 J. E. Doeller, T. S. Isbell, G. Benavides, J. Koenitzer, H. Patel, R. P. Patel, J. R. Lancaster Jr., V. M. Darley-Usmar and D. W. Kraus, Anal. Biochem., 2005, 341, 40-51.

35 C. E. Paulsen and K. S. Carroll, Chem. Rev., 2013, 113, 4633-4679.

36 K. R. Olson, E. R. DeLeon and F. Liu, Nitric Oxide, 2014, 41, 11-26.

37 S. K. Pandey, K.-H. Kim and K.-T. Tang, TrAC, Trends Anal. Chem., 2012, 32, 87-99.

38 E. Bitziou, M. B. Joseph, T. L. Read, N. Palmer, T. Mollart, M. E. Newton and J. V. Macpherson, Anal. Chem., 2014, 86, 10834-10840.

39 B. D. Paul and S. H. Snyder, Nat. Rev. Mol. Cell Biol., 2012, 13, 499-507.

40 M. Goubern, M. Andriamihaja, T. Nubel, F. Blachier and F. Bouillaud, FASEB J., 2007, 21, 1699-1706.

41 D. J. Polhemus and D. J. Lefer, Circ. Res., 2014, 114, 730737.

42 J. W. Elrod, J. W. Calvert, J. Morrison, J. E. Doeller, D. W. Kraus, L. Tao, X. Jiao, R. Scalia, L. Kiss, C. Szabo, H. Kimura, C.-W. Chow and D. J. Lefer, Proc. Natl. Acad. Sci. U. S. A., 2007, 104, 15560-15565.

43 C. K. Nicholson and J. W. Calvert, Pharmacol. Res., 2010, 62, 289-297.

44 Y. Wang, X. Zhao, H. Jin, H. Wei, W. Li, D. Bu, X. Tang, Y. Ren, C. Tang and J. Du, Arterioscler., Thromb., Vasc. Biol., 2009, 29, 173-179. 
45 R. J. Reiffenstein, W. C. Hulbert and S. H. Roth, Annu. Rev. Pharmacol. Toxicol., 1992, 32, 109-134.

46 A. V. Kroll, V. Smorchkov and A. Y. Nazarenko, Sens. Actuators, $B, 1994,21,97-100$.

47 I. S. P. Savizi, H.-R. Kariminia, M. Ghadiri and R. RoostaAzad, Biosens. Bioelectron., 2012, 35, 297-301.

48 J.-L. Chang, G.-T. Wei, T.-Y. Chen and J.-M. Zen, Electroanalysis, 2013, 25, 845-849.

49 Y. Wang, H. Yan and E. F. Wang, Sens. Actuators, B, 2002, 87, 115-121.

50 G. Li, B. J. Polk, L. A. Meazell and D. W. Hatchett, J. Chem. Educ., 2000, 77, 1049.

51 J. Mason, C. J. Cardin and A. Dennehy, Res. Vet. Sci., 1978, 24, 104-108.

52 S. U. Khan, G. F. Morris and M. Hidiroglou, Microchem. J., 1980, 25, 388-395.

53 W. Zhao, J. Zhang, Y. Lu and R. Wang, EMBO J., 2001, 20, 6008-6016.

54 G. Yang, L. Wu, B. Jiang, W. Yang, J. Qi, K. Cao, Q. Meng, A. K. Mustafa, W. Mu, S. Zhang, S. H. Snyder and R. Wang, Science, 2008, 322, 587-590.

55 N. L. Whitfield, E. L. Kreimier, F. C. Verdial, N. Skovgaard and K. R. Olson, Am. J. Physiol.: Regul., Integr. Comp. Physiol., 2008, 294, R1930-R1937.

56 K. R. Olson, M. J. Healy, Z. Qin, N. Skovgaard, B. Vulesevic, D. W. Duff, N. L. Whitfield, G. Yang, R. Wang and S. F. Perry, Am. J. Physiol.: Regul., Integr. Comp. Physiol., 2008, 295, R669-R680.

57 R. A. Dombkowski, M. J. Russell and K. R. Olson, Am. J. Physiol.: Regul., Integr. Comp. Physiol., 2004, 286, R678-R685.

58 Y. H. Chen, W. Z. Yao, B. Geng, Y. L. Ding, M. Lu, M. W. Zhao and C. S. Tang, Chest, 2005, 128, 3205-3211.

59 H. L. Jiang, H. C. Wu, Z. L. Li, B. Geng and C. S. Tang, Di Yi Jun Yi Da Xue Xue Bao, 2005, 25, 951-954.

60 E. Distrutti, L. Sediari, A. Mencarelli, B. Renga, S. Orlandi, E. Antonelli, F. Roviezzo, A. Morelli, G. Cirino, J. L. Wallace and S. Fiorucci, J. Pharmacol. Exp. Ther., 2006, 316, 325-335.

61 L. Chen, S. Ingrid, Y. G. Ding, Y. Liu, J. G. Qi, C. S. Tang and J. B. Du, Chin. Med. J., 2007, 120, 389-393.

62 Q. H. Meng, G. Yang, W. Yang, B. Jiang, L. Wu and R. Wang, Am. J. Pathol., 2007, 170, 1406-1414.

63 B. Geng, Y. Cui, J. Zhao, F. Yu, Y. Zhu, G. Xu, Z. Zhang, C. Tang and J. Du, Am. J. Physiol.: Regul., Integr. Comp. Physiol., 2007, 293, R1608-R1618.

64 T. Li, B. Zhao, C. Wang, H. Wang, Z. Liu, W. Li, H. Jin, C. Tang and J. Du, Exp. Biol. Med., 2008, 233, 1081-1087.

65 G. P. Volpato, R. Searles, B. Yu, M. Scherrer-Crosbie, K. D. Bloch, F. Ichinose and W. M. Zapol, Anesthesiology, 2008, 108, 659-668.

66 S. F. Perry, B. McNeill, E. Elia, A. Nagpal and B. Vulesevic, Am. J. Physiol.: Regul., Integr. Comp. Physiol., 2009, 296, R133-R140.

67 L. Wu, W. Yang, X. Jia, G. Yang, D. Duridanova, K. Cao and R. Wang, Lab. Invest., 2009, 89, 59-67.
68 Y.-H. Chen, W.-Z. Yao, J.-Z. Gao, B. Geng, P.-P. Wang and C.-S. Tang, Respirology, 2009, 14, 746-752.

69 Y.-H. Chen, R. Wu, B. Geng, Y.-F. Qi, P.-P. Wang, W.-Z. Yao and C.-S. Tang, Cytokine, 2009, 45, 117-123.

70 A. K. Mustafa, M. M. Gadalla, N. Sen, S. Kim, W. Mu, S. K. Gazi, R. K. Barrow, G. Yang, R. Wang and S. H. Snyder, Sci. Signaling, 2009, 2, ra72.

71 T. Chang, A. Untereiner, J. Liu and L. Wu, Antioxid. Redox Signaling, 2010, 12, 1093-1100.

72 C. Garcia-Mata and L. Lamattina, New Phytol., 2010, 188, 977-984.

73 C. Alvarez, I. Garcia, I. Moreno, M. E. Perez-Perez, J. L. Crespo, L. C. Romero and C. Gotor, Plant Cell, 2012, 24, 4621-4634.

74 C. Hine, E. Harputlugil, Y. Zhang, C. Ruckenstuhl, B. C. Lee, L. Brace, A. Longchamp, J. H. Treviño-Villarreal, P. Mejia, C. K. Ozaki, R. Wang, V. N. Gladyshev, F. Madeo, W. B. Mair and J. R. Mitchell, Cell, 2015, 160, 132-144.

75 P. Jeroschewski, C. Steuckart and M. Kühl, Anal. Chem., 1996, 68, 4351-4357.

76 D. W. Kraus and J. E. Doeller, J. Exp. Biol., 2004, 207, 3667-3679.

77 G. A. Benavides, G. L. Squadrito, R. W. Mills, H. D. Patel, T. S. Isbell, R. P. Patel, V. M. Darley-Usmar, J. E. Doeller and D. W. Kraus, Proc. Natl. Acad. Sci. U. S. A., 2007, 104, 17977-17982.

78 J. R. Koenitzer, T. S. Isbell, H. D. Patel, G. A. Benavides, D. A. Dickinson, R. P. Patel, V. M. Darley-Usmar, J. R. Lancaster, Jr., J. E. Doeller and D. W. Kraus, Am. J. Physiol.: Heart Circ. Physiol., 2007, 292, H1953H1960.

79 K. R. Olson, N. L. Whitfield, S. E. Bearden, J. St Leger, E. Nilson, Y. Gao and J. A. Madden, Am. J. Physiol.: Regul., Integr. Comp. Physiol., 2010, 298, R51-R60.

80 M. Whiteman, L. Li, P. Rose, C. H. Tan, D. B. Parkinson and P. K. Moore, Antioxid. Redox Signaling, 2010, 12, 11471154.

81 J. Chen, F. H. Wu, W. H. Wang, C. J. Zheng, G. H. Lin, X. J. Dong, J. X. He, Z. M. Pei and H. L. Zheng, J. Exp. Bot., 2011, 62, 4481-4493.

82 K. Suzuki, G. Olah, K. Modis, C. Coletta, G. Kulp, D. Gero, P. Szoleczky, T. Chang, Z. Zhou, L. Wu, R. Wang, A. Papapetropoulos and C. Szabo, Proc. Natl. Acad. Sci. U. S. A., 2011, 108, 13829-13834.

83 Y. Han, F. Zeng, G. Tan, C. Yang, H. Tang, Y. Luo, J. Feng, H. Xiong and Q. Guo, Cell. Physiol. Biochem., 2013, 31, 795-804.

84 C. Huang, J. Kan, X. Liu, F. Ma, B. H. Tran, Y. Zou, S. Wang and Y. Z. Zhu, PLoS One, 2013, 8, e69205.

85 K. Modis, C. Coletta, K. Erdelyi, A. Papapetropoulos and C. Szabo, FASEB J., 2013, 27, 601-611.

86 K. R. Olson, E. R. Deleon, Y. Gao, K. Hurley, V. Sadauskas, C. Batz and G. F. Stoy, Am. J. Physiol.: Regul., Integr. Comp. Physiol., 2013, 305, R592-R603.

87 U. Hasegawa and A. J. van der Vlies, MedChemComm, 2015, 6, 273-276. 
88 E. A. Ostrakhovitch, S. Akakura, R. Sanokawa-Akakura, S. Goodwin and S. Tabibzadeh, Exp. Cell Res., 2015, 330, 135-150.

89 Y. Sun, Y. Huang, R. Zhang, Q. Chen, J. Chen, Y. Zong, J. Liu, S. Feng, A. D. Liu, L. Holmberg, D. Liu, C. Tang, J. Du and H. Jin, J. Mol. Med., 2015, 93, 439-455.

90 P. Huang, S. Chen, Y. Wang, J. Liu, Q. Yao, Y. Huang, H. Li, M. Zhu, S. Wang, L. Li, C. Tang, Y. Tao, G. Yang, J. Du and H. Jin, Nitric Oxide, 2015, 46, 192-203.

91 M. D. Luque de Castro and M. C. Herrera, Biosens. Bioelectron., 2003, 18, 279-294.

92 W. John Albery, A. E. G. Cass, B. P. Mangold and Z. X. Shu, Biosens. Bioelectron., 1990, 5, 397-413.

93 J. Zhao, R. W. Henkens and A. L. Crumbliss, Biotechnol. Prog., 1996, 12, 703-708.

94 Y. Yang, M. Yang, H. Wang, J. Jiang, G. Shen and R. Yu, Sens. Actuators, B, 2004, 102, 162-168.

95 L. Liu, Z. Chen, S. Yang, X. Jin and X. Lin, Sens. Actuators, $B, 2008,129,218-224$.

96 N. Z. M. Poor, L. Baniasadi, M. Omidi, G. Amoabediny, F. Yazdian, H. Attar, A. Heydarzadeh, A. S. H. Zarami and M. H. Sheikhha, Enzyme Microb. Technol., 2014, 63, 7-12.
97 P. Nagy, Z. Pálinkás, A. Nagy, B. Budai, I. Tóth and A. Vasas, Biochim. Biophys. Acta, 2014, 1840, 876-891.

98 K. R. Olson, J. Exp. Biol., 2008, 211, 2727-2734.

99 K. R. Olson, R. A. Dombkowski, M. J. Russell, M. M. Doellman, S. K. Head, N. L. Whitfield and J. A. Madden, J. Exp. Biol., 2006, 209, 4011-4023.

100 K. R. Olson and N. L. Whitfield, Antioxid. Redox Signaling, 2010, 12, 1219-1234.

101 Z.-G. Li, M. Gong, H. Xie, L. Yang and J. Li, Plant Sci., 2012, 185-186, 185-189.

102 L.-Y. Hu, S.-L. Hu, J. Wu, Y.-H. Li, J.-L. Zheng, Z.-J. Wei, J. Liu, H.-L. Wang, Y.-S. Liu and H. Zhang, J. Agric. Food Chem., 2012, 60, 8684-8693.

103 Y.-H. Chen, W.-Z. Yao, Y.-L. Ding, B. Geng, M. Lu and C.-S. Tang, Pulm. Pharmacol. Ther., 2008, 21, 40-46.

104 M. Zheng, Q. Zeng, X. Q. Shi, J. Zhao, C. S. Tang, N. L. Sun and B. Geng, Chin. Med. J., 2011, 124, 36933701.

105 F. Zhang, X. Li, C. Stella, L. Chen, Y. Liao, C. Tang, H. Jin and J. Du, J. Pediatr., 2012, 160, 227-231.

106 J. Yang, H. Li, T. Ochs, J. Zhao, Q. Zhang, S. Du, Y. Chen, P. Liu, Y. Wang, X. Feng, C. Zhang, C. Tang, J. Du and H. Jin, J. Pediatr., 2015, 166, 965-969. 